\title{
A NÉPESSÉG SZÁMÁNAK, ÖSSZETÉTELÉNEK ÉS TERÜLETI ELOSZLÁSÁNAK VÁLTOZÁSA DEBRECENBEN 1939 ÉS 1990 KÖZÖTT
}

\author{
(The number, struture and spatial distribution of population in Debrecen, \\ between 1939-1990)
}

\section{KOZMA GÁBOR}

A II. világháború után nagyvárosainkban lezajlott változások jelentősen megváltoztatták a népesség területi elhelyezkedését, az egyes városrészek lakosságának jellemzóit (pl. korösszetétel, foglalkozási szerkezet stb.). Dolgozatom célja a Debrecenben 1930-as évek vége és 1990 között lezajlott ilyen jellegú változások bemutatása

Vizsgálataimat a központi belterületre végeztem, és ennek a területét osztottam fel 42 olyan körzetre, amelyek véleményem szerint egy-egy azonos tulajdonságokkal jellemezhető városrészt foglalnak magukba ( 1 . ábra). A változások megértéséhez azonban indokolt bemutatni a város lakóterületeinek a fejlődését is, és ezért elöször ezt a témakört elemzem.

\section{$A$ város lakóterületeinek a fejlődése}

Az 1930-as években Debrecen lakóterületeire és általában a városra a földszintes házak dominanciajja volt a jellemzö: 1930-ban a város lakásainak 92,9\%-a fóldszintes házakban feküdt. Az emeletes épületek jelentős része a település fơutcáján (Piac utca) illetve a belöle kiágazó mellékutcák elején helyezkedett el. Innen a történelmi belváros peremi részei felé haladva a településkép fokozatos fellazulását lehetett megfigyelni (a történelmi belváros az 1., a 2., a 3., a 4., az 5 . és a 6 . körzetet foglalja magába).

A történelmi belváros peremén az ún. hóstát helyezkedett el (15. illetve 26. körzet): a XVIII. század végén kiosztott apró telkeken falusias házak sorakoztak egymás mellett. A történelmi városmagon kívül feküdtek a kertségek, melyek a belváros túlzsúfoltsága miatt a XIX. század végén kezdtek benépesülni.

A második világháború igen jelentős pusztítást okozott a városban. Az 1944. júniusi és szeptemberi amerikai bombázások, illetve az októberben lezajlott harcok kővetkeztében az 1941-ben összeírt 13502 házas ingatlanból 4797 szenvedett súlyosabb sérülést és ezek közül 690 rommá vált '.

A második világháború és az 1950-es évek vége között lezajlott építkezések egy része a háborús pusztításokhoz kötődött. Így például a belváros déli területein (2. körzet) a Petőfi tér, Hunyadi és Deák Ferenc utcák által határolt lakóterület olyan súlyosan megsérült, hogy bár ezen városrész újjápépítésére több terv is készült ${ }^{2}$, végül az egész lakótömböt rommá nyilvánították és lebontották. 
1. ÁBRA

Debrecen körzetei

(The main parts of the city Debrecen)

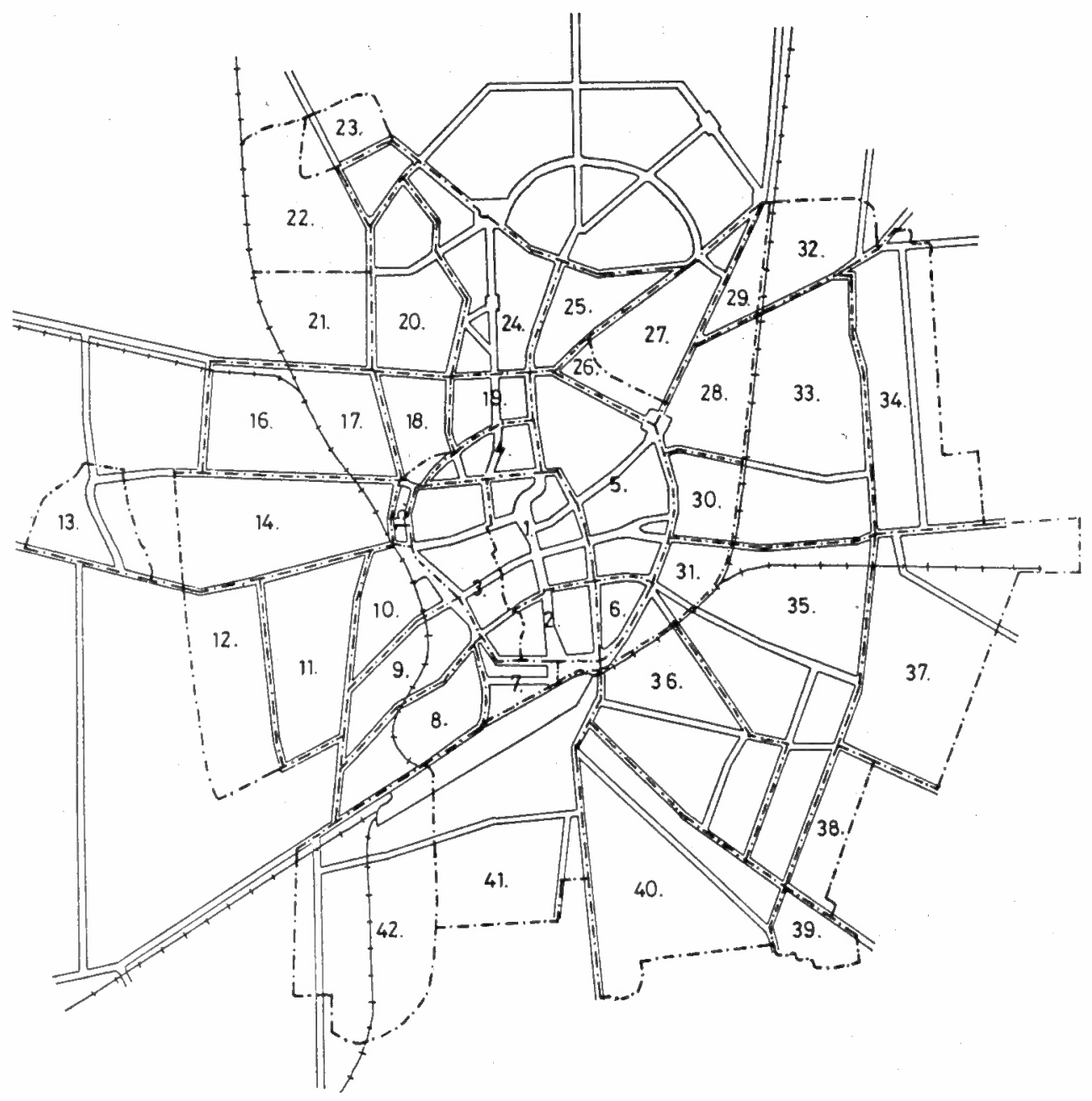


A népesség számának, összetételének és területi eloszlásának változása Debrecenben 1939 és 1990 között Tér és Társadalom 10. évf. 1996/2-3. 123-132. p.

A pénzhiány illetve a rendelkezésre álló tóke más irányú felhasználása miatt új beruházásokra alig került sor. Egyrészt a Böszörményi út mentén az 1940/50-es évek fordulóján egy 350 családi házból álló lakótelep létesült (21. körzet), másrészt az Április 4. útján illetve a Hajnal utcán felépültek az első többszintes állami lakóházak (31. körzet északi része).

A korábban leírtak fényében egyáltalán nem meglepő, hogy az ÉM. Városterv által 1957-ben végzett - az egész városra kiterjedő - épület- és lakáshelyzet-vizsgálat igen kedvezótlen képet állapított meg. A felmérés szerint a lakóépưletek 80,5\%-a, a lakásoknak pedig 71,3\%-a volt avult illetve egészségtelen minőségú és a helyzetet súlyosbította, hogy ezekben a lakásokban élt a város lakosságának 68,3\%-a. Igen kedvezótlen képet mutatott a lakások kora is: a második világháború és a vizsgálat kezdete között csak 2883 darab lakást építettek, melyek a település lakásállományának 9,4\%-át alkották ${ }^{3}$.

Mindezen tények következtében szinte természetes, hogy a Kalata Gyula vezetésével 1961-ben elkészített általános rendezési terv igen radikális változásokat javasolt. A terv hosszú távlatban azzal számolt, hogy a belterületi lakosságszám az 1960 . évi 105000 förỏl 1985-ig 160000 före fog nöni ${ }^{4}$. Ezen népesség elhelyezésére összesen 50000 lakásra lesz szükség, mely figyelembe véve a meglévő 2807 szuikséglakás, a 2393 életveszélyes és használhatatlan illetve a 2800 erỏsen avult lakás szanálását a tervidószakban 27300 új lakás felépítését teszi szükségessé, melyből 16500 darabot az első 15 éves lakásépítési terv keretében kell majd elkészíteni.

A város amúgy is kiterjedt lakóterülete további növekedésének meggátolása illetve gazdaságossági szempontok (közmü- és szolgáltatási intézményekkel való ellátás, közlekedés fejlesztése) miatt a terv a földszintes házakkal szemben a többemeletes épületeket részesítette elönyben. Ezek elhelyezésére azokat a város belsỏ részén fekvő területeket jelölte ki, melyek egyrészt jól el voltak látva közmúvekkel, másrészt alacsony beépítettségủek illetve beépítetlenek voltak (Tanácsköztársaság út déli szakasza, Libakert 19. körzet; Vẻnkert - 18. körzet; Hadházi úti temető - 27. körzet déli része; Dobozi temető - 30. körzet).

Sürübb lakosságot és emeletes beépitést tartalmazott a terv az Újkert (20. körzet), a Sétakert és a Sestakert (24. és 25. körzet) teruletére, valamint a belváros egyes részeire (pl. Petőfi tẻr és környéke, Jászai Mari tér és környéke). A családi házat építeni szándékozók számára a Hatvan utcai kertet (14. körzet), a Tócóskertet (11. körzet), a Széchenyikertet (10. körzet), a Homokkertet (36. kőrzet) és a Csapókertet (33. körzet) jelölték ki.

A terv egyes területek esetében azok akkori szinten történő meghagyását illetve kisebb városrészek visszafejlesztését is javasolta (ezek tehát semmilyen támogatásban nem reménykedhettek). Ezek közül a legnagyobb a Nagy Sándor-telep (13. körzet) volt, melynél elsősorban az egészségtelen talajviszonyokkal indokolták a visszafejlesztés szükségességét.

Az 1960-as években lezajlott építkezések nagyjából követték a terveket. Debrecen első igazi lakótelepeként elkészült a Szabadság úti MGM lakótelep (29. körzet északi része) valamint a Libakertben az Új Élet parki lakótelep, és megkezdődött a többszintes építkezés a Sestakertben, az egykori Dobozi temető területén, a Petőfi és Jászai Mari tér környékén és az Erzsébet és Késes utcák (7. körzet) által határolt városrészekben.

A kétségkívül lezajló fejlesztések ellenére egyre súlyosabban jelentkezó mennyiségi és minöségi lakáshiány leküzdése érdekében a Szokolai Örs irányításával 1969-ben 
elkészített újabb általános rendezési terv a korábbinál is radikálisabban fogalmazott. A tervezök elörejelzése szerint a város népessége 2000-ig 300000 fơre fog nővekedni, és számukra összesen kb. 86700 darab lakásra lesz szükség. A terv alapgondolata azonban az volt, hogy Debrecen olyan nagy kiterjedésü, kis laksürüségú város, melynek nem szabad növelni a belterületét, és ennek megfelelően kimondták, hogy a vasútvonalak és a Nagyerdő közötti területen a lakóterületek beépítése csak többszintes lehet ${ }^{5}$.

A terv alapelvként fogalmazta meg a rekonstrukciót, azaz a belváros egyes terilleteinek illetve a kijelölt - fơleg a belvárostól nyugatra fekvő - kertségi és hóstáti városrészeknek a teljes lebontását (a tömeges lakásépítkezésekhez ugyanis nagy szabad területre volt szükség) és többszintes épuletekkel történő pótlását, melyhez az építőipari hảtteret az 1971-ben megnyilt házgyár biztosította.

Az elmúlt húsz évben végbement változások tőbb pontban követték az 1970-es tervet. Felépült a Vénkerti-, az Újkerti- és a Tócoskerti- és a Dobozi-lakótelep, és a 1990-ben itt élt a város lakosságának 33\%-a. A burzsoá életvitel kerülnivaló jelképeivel való leszámolás szellemében, építve a város elókelóbb lakosságának a lakótelepek által kínáltnál elviselhetóbb életfeltételek utáni igényére, az 1920-as, 1930-as években kiformálódott Sesta- és Sétakerti villanegyedet építészetileg igénytelen társasházépítkezésekkel roncsolták szét. Még nagyobb problémát jelentett, hogy a lakótelepek a belváros területén is megjelentek (Csemete utcai, Mester utcai, Csapó utcai, Burgundia utcai és Klaipeda utcai lakótelep) és egy a korábbitól teljesen eltéró városképi elemet hoztak be Debrecen szívébe.

Az új lakótelepek felépítésére koncentráló városfejlesztés azzal a negatív következménnyel is járt, hogy kevesebb figyelem és pénz jutott a többi kertségre valamint a belváros eredeti állapotban megmaradt részeire, és ennek következtében a kertségekben az intézményi és hálózati infrastruktúra nem fejlődött a kívánt szinten. A vezetékes vízhálózatot ugyan az 1980-as évek második felében sikerült kiépiteni, szennyvízcsatornával illetve csapadékvíz-csatornával azonban a terilletek döntő része ma sincs ellátva.

Az 1980-as évek második felében a város lakóterületeit vizsgálva azonban már pozitív változásokat is meg lehetett figyelni. A belvárosban felépült a Béke-Wesselényi utcai lakótelep (6. körzet), mely megjelenésével igyekszik alkalmazkodni környezetéhez. Másrészt a kertségekben - a Tócó-patak völgyében (12. körzet), az Akadémia és a Vezér utca környékén (22. körzet) - olyan városrészek létesültek, melyek az ottlakók számára tényleg biztosítják az egészséges emberi élet feltételeit.

\section{Változások az egyes körzetek demográfiai viszonyaiban}

A korábban bemutatott változások jelentösen módosították a város lakosságának településen belüli eloszlását (1. táblázat). A táblázatban az 1970-es, az 1980-as és 1990-es adatok az állandó népességre vonatkoznak. Az 1939-es statisztikák csak a jelenlévõ népességet tartalmazzák, ezekből az adatokból azonban a torzítások csökkentése érdekében kivontam a laktanyákban, kórházakban, kollégiumokban összeírtakat, mint olyan személyeket, akik biztosan nem debreceni lakosok.

A korösszetétel változásainak bemutatásához a fiatalkorúak (0-14 év) és az időskorủak (60 év felett) arányának hányadosát használtam (2. táblázat). 


\section{Kozma Gábor :}

A népesség számának, összetételének és területi eloszlásának változása Debrecenben 1939 és 1990 között Tér és Társadalom 10. évf. 1996/2-3. 123-132. p.

\section{TÁBLÁZAT}

Debrecen lakosságának körzetenkénti eloszlása 1939-ben, 1970-1990-ben (fó) ${ }^{6,7,8,9}$

(The distribution of the population in Debrecen, by districts in 1939, 1970-1990)

\begin{tabular}{|l|r|r|r|r||r|r|r|r|r|}
\hline Körzet & \multicolumn{1}{|c|}{1939} & \multicolumn{1}{|c|}{1970} & \multicolumn{1}{|c|}{1980} & \multicolumn{1}{|c|}{1990} & Körzet & 1939 & 1970 & 1980 & 1990 \\
\hline 1. & 7526 & 10501 & 7585 & 6299 & 22. & - & - & - & 3286 \\
\hline 2. & 4058 & 6751 & 5532 & 4460 & 23. & 883 & 974 & 3063 & 1613 \\
\hline 3. & 8452 & 8564 & 6045 & 4555 & 24. & 1467 & 7436 & 11742 & 11759 \\
\hline 4. & 2581 & 3425 & 8288 & 6581 & 25. & 557 & 2564 & 3923 & 3285 \\
\hline 5. & 13759 & 13330 & 14891 & 11278 & 26. & 2177 & 1882 & 1381 & 1189 \\
\hline 6. & 1900 & 2195 & 1293 & 2164 & 27. & 986 & 2067 & 4972 & 5127 \\
\hline 7. & 1756 & 1387 & 2833 & 2175 & 28. & 3752 & 3820 & 2767 & 2264 \\
\hline 8. & 1953 & 1493 & 2782 & 2446 & 29. & 514 & 1551 & 1713 & 1705 \\
\hline 9. & 1044 & 1440 & 1193 & 1018 & 30. & 790 & 4903 & 9296 & 7357 \\
\hline 10. & 520 & 938 & 1078 & 929 & 31. & 1212 & 1715 & 1693 & 1269 \\
\hline 11. & 1508 & 2250 & 1296 & 21974 & 32. & 969 & 1375 & 1788 & 1944 \\
\hline 12. & - & 265 & 634 & 2663 & 33. & 5595 & 6593 & 5801 & 5519 \\
\hline 13. & - & 3430 & 3366 & 2520 & 34. & - & 5798 & 6806 & 8012 \\
\hline 14. & 1294 & 2905 & 2902 & 2207 & 35. & 998 & 2287 & 1317 & 975 \\
\hline 15. & 1677 & 1182 & 946 & 732 & 36. & 3655 & 4249 & 3692 & 3387 \\
\hline 16. & 792 & 990 & 789 & 718 & 37. & 1885 & 4357 & 5138 & 6233 \\
\hline 17. & 911 & 1018 & 733 & 519 & 38. & - & 711 & 631 & 466 \\
\hline 18. & 726 & 783 & 11968 & 9344 & 39. & - & 128 & 191 & 1879 \\
\hline 19. & 824 & 7893 & 7087 & 5422 & 40. & 905 & 3471 & 4079 & 4112 \\
\hline 20. & 1417 & 2233 & 15693 & 22732 & 41. & 797 & 1668 & 2325 & 2188 \\
\hline 21. & - & 1886 & 1586 & 948 & 42 & - & 1701 & 1589 & 2076 \\
\hline
\end{tabular}

Forrás: Népszámlálási adatokból saját szerkesztés

A városmag (1. és 2. körzet) esetében 1970-ig jelentős lakosságszám-növekedés figyelhető meg, mivel ebben az időszakban ez a terület még kedvelt volt a lakosság kőrében, az új többszintes épületek felépülése illetve a korábbi többszobás polgári lakások felosztása pedig lehetőséget teremtett a népesség itteni letelepedésére. Az elmúlt húsz évben azonban a belváros más célú hasznosításának (elsösorban közintézmények és közlekedési célra hasznosított területek) elöretörése illetve a lakásállomány fokozatos elavulása miatt csökkent a lakosságszám.

Az 1960-as években felépített új. házakba nagyszámú fiatal házaspár is költözött és ennek illetve a belváros már korábban említett "népszerüségének" köszönhető az 1970-es kiegyensúlyozott korstruktúra. Az 1970-es és 1980-as évtizedben azonban a fiatal korosztályok elköltöztek innen (az okokról egy kicsit késỏbb szólok), és ennek következtében elöregedés ment végbe.

A városmagot övezö terület (3., 4., 5., és 6. körzet) esetében 1939 és 1970 között nem lehet általános tendenciát megállapítani: egyaránt megfigyelhetỏ lakosságszám-növekedés, csökkenés illetve stagnálás. Az elmúlt húsz évben azonban már markáns fejlődési típusokat lehet elkülöníteni. A városmagot nyugatról övező városrészben (3. körzet) nem 
történt jelentősebb építkezés és így ebben a korszakban a városmagban 1970 után megfigyelhető jelenségek érvényesültek.

\section{TÁBLÁZAT}

A fiatalkorúak (0-14 éves kor) és az időskorúak (60 év felett) aránya hányadosának változása 1970 és 1990 közöttt $6,7,9$

(The changes of the ratio of juvenile - 0-14 years old - and old - over 60 years - people, between 1970 and 1990)

\begin{tabular}{|c|c|c|c||c|c|c|c|}
\hline Körzet & 1970 & 1980 & 1990 & Körzet & 1970 & 1980 & 1990 \\
\hline 1. & 1,02 & 0,72 & 0,53 & 22 & - & - & 6,07 \\
\hline 2. & 1,32 & 0,79 & 0,46 & 23. & 1,20 & 0,91 & 0,52 \\
\hline 3. & 1,02 & 0,73 & 0,59 & 24 & 2,03 & 2,24 & 0,82 \\
\hline 4. & 0,72 & 2,65 & 1,02 & 25 & 1,65 & 1,68 & 0,63 \\
\hline 5. & 0,67 & 0,99 & 0,59 & 26. & 0,70 & 0,64 & 0,55 \\
\hline 6. & 0,86 & 0,64 & 8,08 & 27 & 1,01 & 1,94 & 1,34 \\
\hline 7. & 4,45 & 1,71 & 0,50 & 28. & 0,73 & 0,56 & 0,44 \\
\hline 8. & 0,82 & 2,48 & 2,05 & 29. & 1,96 & 1,38 & 0,91 \\
\hline 9. & 1,05 & 0,71 & 0,48 & 30. & 2,72 & 2,04 & 0,73 \\
\hline 10. & 0,85 & 1,00 & 0,74 & 31. & 2,42 & 1,06 & 0,36 \\
\hline 11. & 1,04 & 0,59 & 8,14 & 32. & 0,96 & 1,24 & 0,83 \\
\hline 12. & 0,23 & 0,62 & 42,4 & 33. & 1,02 & 0,86 & 0,59 \\
\hline 13. & 1,84 & 1,97 & 1,19 & 34. & 2,11 & 1,81 & 1,40 \\
\hline 14. & 1,64 & 1,47 & 0,75 & 35. & 1,88 & 0,77 & 0,79 \\
\hline 15. & 0,67 & 0,54 & 0,57 & 36. & 0,98 & 0,76 & 0,76 \\
\hline 16. & 0,86 & 0,69 & 0,63 & 37. & 1,49 & 1,34 & 1,44 \\
\hline 17. & 0,88 & 0,51 & 0,55 & 38. & 1,13 & 1,03 & 0,70 \\
\hline 18. & 0,77 & 4,57 & 1,00 & 39. & 2,67 & 1,62 & 4,04 \\
\hline 19. & 3,46 & 1,16 & 0,37 & 40. & 1,69 & 1,65 & 1,05 \\
\hline 20. & 1,09 & 8,49 & 3,09 & 41. & 2,38 & 2,43 & 1,10 \\
\hline 21. & 2,78 & 1,05 & 0,49 & 42. & 1,73 & 1,04 & 1,77 \\
\hline
\end{tabular}

Forrás: Népszámlálási adatok alapján saját szerkesztés

Az 1970-es években a 4. és 5. körzetet érintette az északi és keleti tehermentesító utak elkészítéséhez illetve a Csapó utca kiegyenesítéséhez kapcsolódó lakótelep-építés, és ennek következtében 1970 és 1980 között nött a lakosságszám és fiatalodott a népesség (ezek a tendenciák természetesen markánsabbak voltak 4. körzetben, melyet nagyobb mértékben átformáltak az építkezések).

$\mathrm{Az}$ 1980-as évtizedben azonban ezekben a városrészekben a korábbival ellentétes tendenciák váltak uralkodóvá. Egyrészt a beköltöző fiatal házasok egy része számára a gyermekek megszületésével és felnövésével a lakások kicsivé váltak, így elköltöztek innen és a helyuiket kisebb családok (gyakran nyugdíjasok) foglalták el. Másrészt a fiatal házasok gyerekeinek nagy része a felnőttkor elérése után elhagyta ezt a városrészt, amely a továbbiakban csak a szüleiknek szolgált lakóhelyül.

Mindezen folyamatok illetve a körzetek hagyományos beépítettségũ területeirỏl történö fôleg a fiatalokat érintö - elvándorlás hatására az 1980-as években ezekben a városrészekben népességfogyás és elöregedés ment végbe. A Béke-Wesselényi utcai 
lakótelepet (6. körzet) az 1980-as évek elején kezdték el építeni, és ez indokolja az 1980 és 1990 között gyarapodást és az igen fiatal korösszetételt.

A belvárost peremén elhelyezkedő hóstáti részek (15. és 26. körzet) már 1939-ben is igen zsúfoltak és elavult lakásokkal rendelkezỏ területek voltak. A második világháború után itt jelentősebb épitkezés nem ment végbe, és így nem csoda, hogy az 1939 és 1970 közötti kismértékủ gyarapodás után az elmúlt húsz évben itt csökkent a lakosságszám, a korstruktúrára pedig az egész időszakban az elöregedettség volt a jellemzó.

A kertségek vizsgálata során több jellegzetes típust is el lehet különíteni. A "lakótelepek" esetében egy sajátos lakosságszám alakulás figyelhetỏ meg. A Libakertben (19. körzet), a Kertvárosban (21. körzet) és a 31. körzetben élök száma 1939 és 1970 között növekedett igen dinamikusan (az előbbi esetében az építkezés fö idószaka az 1950/60-as évek fordulója volt, az utóbbi házai pedig az 1950-es években épültek), és 1970-ben ezekre területekre egy fiatal korösszetétel volt a jellemzö. Az elmúlt húsz évben azonban érvényesulitek a 4 . és 5 . körzetekben megfigyelt jelenségek, és az ottanihoz hasonló tendenciák mentek végbe.

Az 1960/70-es évek fordulóján épült fel az Erzsébet utcai (7. körzet) és a Dobozilakótelep (30. körzet), és így ezekben városrészekben a népességmaximum 1980-ban volt, ekkorra azonban a korstruktúrában 1970-hez képest már beindult az elöregedés. A Vénkerti-lakótelep (18. körzet) az 1970-es évek terméke (lásd az 1980-as korösszetételt), az elmúlt évtizedben azonban itt - és az előző két körzetben - is jellegzetes, és markáns folyamattá vált az elöregedés. Az 1980-as évekre tehetỏ az újkerti (20. körzet) és a tócóskerti (11. körzet) építkezések fỏ időszaka, és ezzel magyarázható az 1990-es maximum és a fiatal korösszetétel.

A Vénkerthez és a Dobozi-lakótelephez hasonló változásokat lehet megfigyelni a Sestaés Sétakert (24. és 25. körzet) esetében is. Az ebben a városrészben az 1920-as és 1930-as években kifejlődött villanegyedet az 1960-as és 1970-es években egy többszintes társasházakból illetve egy-két helyen lakótelepszerủ épületekbỏl álló zóna váltotta fel. $\mathrm{Az}$ 1970-es évek végére azonban az építési lehetőségek jelentős részét kihasználták, és ennek következtében 1980 után - amellett, hogy a terület városon beluli megítélése még napjainkban is igen kedvező - érvényestiltek a korábban ismertetett tendenciák és kismértékben csökkent a lakosságszám és az 1980-as évtizedben jól foghatóvá vált az elöregedés.

Az államilag támogatott lakásépítkezések által nem érintett kertségek esetében három típus különíthetơ el. Az 1930-as évek végére már benépesült a Homokkert (36. körzet), Csapókert (33. körzet), Köntöskert (16. körzet), Csigekert (17. körzet), Postakert (9. körzet) jelentős része, a második világháború után új házhelyek kialakítására alig nyílt lehetőség és ennek következtében 1970-ig csak kismértékú népességnỏvekedés ment végbe. Az 1970-es és 1980-as évtizedben azonban az ipar terjeszkedését elösegítendó céllal elrendelt szanálások és építési tilalmak (pl. Homokkert, Köntöskert, Csigekert), és részben az utóbbi következtében elöálló - és fóleg a fiatalok elvándorlását kiváltó infrastrukturális elégtelenségek miatt csökkent ezen városrészek népességszáma, a korösszetételre pedig az az 1970-es - már akkor is öregebbnek számító - állapothoz képest az elöregedés folyamata volt a jellemzỏ.

$\mathrm{Az}$ 1970-es évek végére tehető a Hatvan utcai kert (14. körzet), a BoldogfalvakertEpreskert (41. körzet) és a Széchenyikert (10. körzet) telítődése, és ezekben a városrészekben 1980 után kezdett el csökkenni és öregedni népesség. 
Napjainkban a népességnövekedés színterei azok a kertségek, melyek egy része a második világháború előtt még nem is tartozott a város belterületéhez: pl. a Gerébi-telep és a Szabadság-telep (34. körzet), a Lenc-telep (39. körzet), a Tégláskert (42. körzet), Akadémia és Vezér utcai lakótelep (22. körzet), Tócó-völgy (12. körzet), másik részükre pedig a ritkás betelepülés volt a jellemzö (Bozzay-telep 37. körzet) és a Kerekestelep (40. körzet). Ezen városrészek esetében végig megfigyelhetó volt az új házhelyek kialakítása, új házak felépítése és így a népességszám-növekedés. A korösszetétel szempontjából ezeket a körzeteket két csoportra lehet osztani. Ott, ahol az épitkezés az 1980-as években vett nagyobb lendületet 1990-ben egy alapvetỏen fiatal lakosság élt (pl. Tócó-völgy, Lenctelep, Akadémia és Vezér utca környéke), míg a többi területen egy kiegyensúlyozottabb korstruktúrát lehetett megfigyelni.

A második világháború után a város foglalkozási szerkezetében is jelentős eltolódások zajlottak le, amelyek különbözőképpen jelentkeztek az egyes körzetekben. Az 1970 és 1990 közötti trendeket elemezve (3. táblázat) meg lehet állapítani, hogy jelentősen csökkent az iparban, nőtt az egyéb területeken foglalkoztatottak aránya, míg a mezőgazdaságban dolgozóké lényegében nem módosult.

\section{TÁBLÁZAT}

A foglakozási szerkezet változása az általam vizsgált 42 körzetben (\%)

(The changes in the structure of employment)

\begin{tabular}{|l|c|c|c|}
\hline & 1970 & 1980 & 1990 \\
\hline ipar & 50 & 43 & 38 \\
\hline mezỏgazdaság & 5 & 4 & 5 \\
\hline egyéb területek & 45 & 53 & 57 \\
\hline
\end{tabular}

Forrás: Népszámlálás, 1970, 1980, 1990.

A változások térbeli megjelenésének vizsgálata során a legnagyobb figyelmet az iparban és egyéb területeken dolgozókra fordítottam, a mezỏgazdaságban foglalkoztatottakkal csak érintőlegesen foglalkoztam.

A mezőgazdaságban foglalkoztatottak aránya a legtöbb körzetben mind a három időpontban az átlag körül, illetve az alatt mozgott. Ez az adat 1970-ben még két - jól összefüggő - területen volt lényegesen nagyobb az átlagnál ( $8 \%$ felett): a város nyugati peremén (10., 11., 13., 14., 16., 20., 21 . és 23. körzetek), ahol a jó minőségü földeken igen fejlett növénytermelést folytattak, valamint a délkeleti városrészben (38., 39. és 40. körzetek). A két koncentrálódás közül 1990-re csak délkeleti maradt meg, míg a nyugati szinte teljesen megszünt: a lakótelep- és társasházépítkezések a lakosság jelentős kicserélődéséhez vezettek (az egyedüli kivételt a beépítési jelleg vonatkozásában szinte változatlan 16. körzet képezte), és így ezekben a körzetekben a mezögazdaságban dolgozók aránya nagymértékben csökkent.

A másik két foglalkozási kategória helyzetét egymáshoz való viszonyuk (iparban foglalkoztatottak aránya/egyéb terulleteken foglalkoztatottak aránya) bemutatásával elemzem (2. ábra). 


\section{Kozma Gábor :}

A népesség számának, összetételének és területi eloszlásának változása Debrecenben 1939 és 1990 között Tér és Társadalom 10. évf. 1996/2-3. 123-132. p.

TÉT $1996 \cdot 2-3$

A népesség számának.

\section{2. ÁBRA}

Az iparban és az egyéb területen foglalkoztatottak arányának hányadosa (felül 1970-es, alul 1990-es állapot)

(Theshare of the ratio of industrial workers and service employees) (above 1970, below 1990)

[III] -0.78

$0,79-0,98$

$0.99-1,18$

जIIV $1,19 \cdot 1,38$

EDT 1,39 -
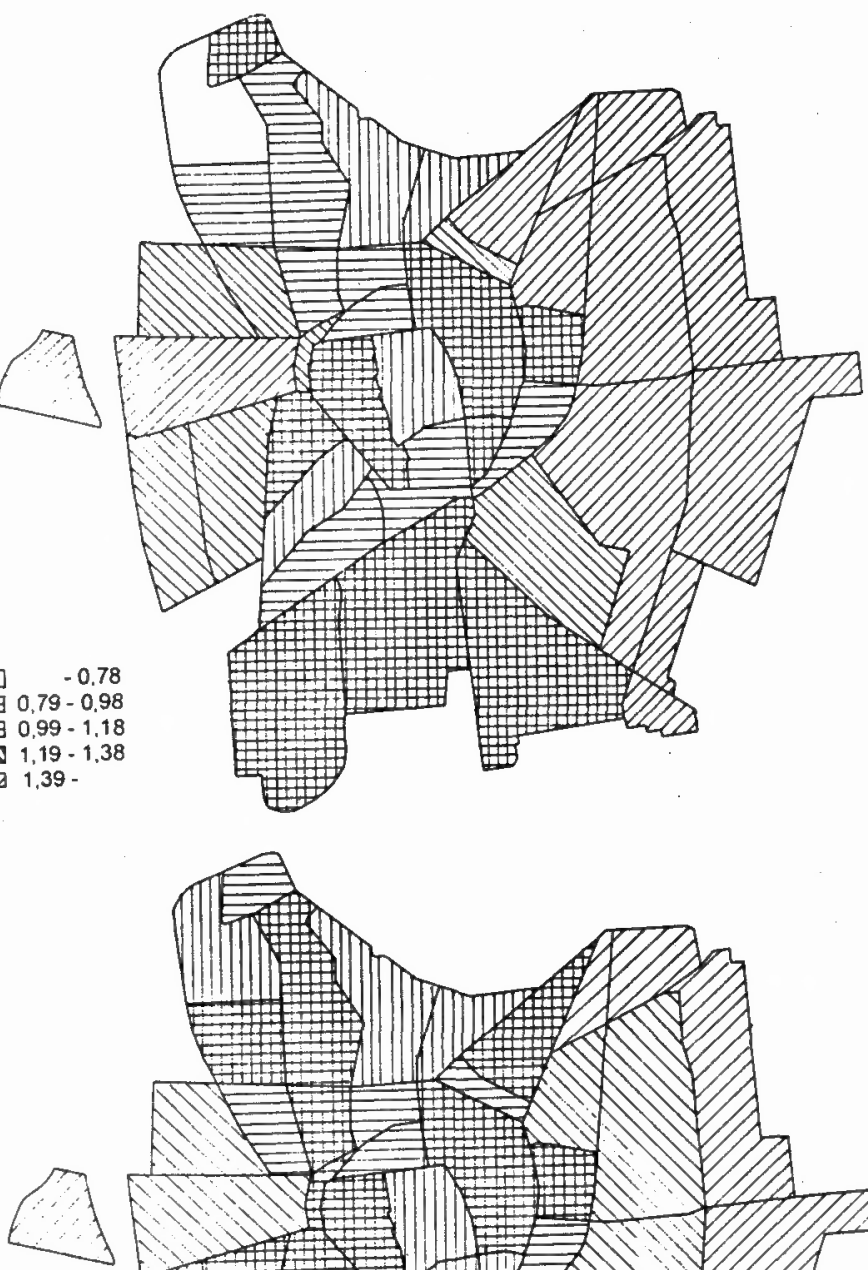

साII) $\quad 0.52$

$\Longrightarrow 0,53-0,62$

$0,63-0,72$

aाय $0.73-0,82$ WID 0.83 -

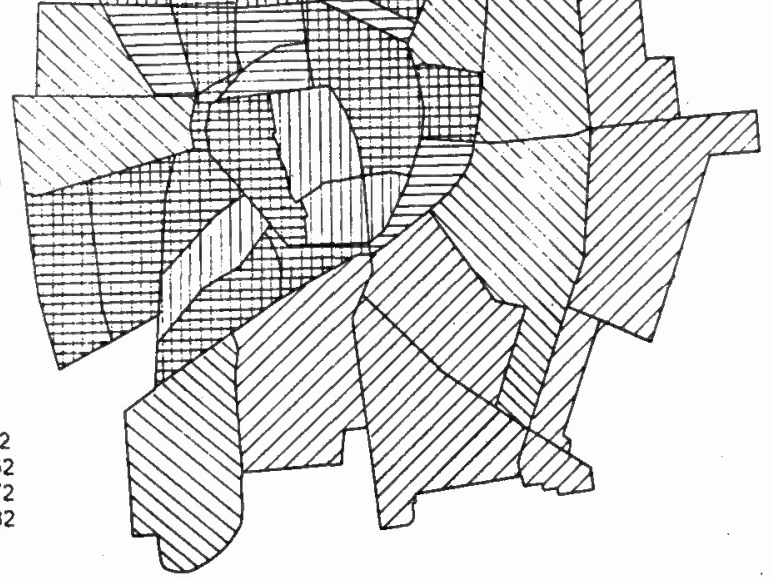


Az ábráról a következó fontosabb trendek olvashatók le:

- Az egész periódusban az egyéb területeken dolgozók dominanciája volt a jellemzỏ a belvárosra (1. és 2 . körzet), és a jómódúak által lakott Séta és Sestakertre (24. és 25 körzet). Ugyanebbe a kategóriába emelkedett 1990-re a városközponthoz való közelsége miatt népszerú Béke-Wesselényi úti lakótelep (6. körzet), valamint a Vezér utca és környéke (22. körzet).

- A nagyméretủ lakótelep-építés által érintett városrészekre áitalában az átlag körüli érték a jellemzó: 1990-re ebbe a csoportba került a Tócóskert, Vénkert, Újkert, Dobozi-lakótelep.

- A Budapest-Nyíregyháza vasútvonaltól keletre fekvö területeken (amelyek zöme kertségi beépítésü) az átlag feletti arányban laktak az iparban dolgozók.

\section{Irodalom}

Az 1970. évi népszámlálás 10.a kőtet. Hajdú-Bihar megye és Debrecen számlálókörzeti és külterületi adatai. $\mathrm{KSH}$.

Az 1980. évi népszámlálás 9.b kőtet. Hajdú-Bihar megye és Debrecen számlálókörzeti és külterületi adatai.

Az 1990. évi népszámlálás debreceni adatai.

Csobán Endre levéltári hagyatéka. Hajdú-Bihar Megyei Levéltár XV. 22/b. 1. doboz

Debrecen Városfejlesztési Program. ÉM. VÁTI 1958. 28-30.o.

Debrecen, általános rendezési terv ismertetése. Debrecen, 1969. 16.0.

Dénesi Ö. (1954) A Petöfi tér rendezése és a tervpályázat eredménye. Városépitési Szemle 1.sz. 35-38.o.

Sápi L. (1972) Debrecen építés-és településtörténete. Debrecen, 86.0.

Város és városfejlesztés. Debrecen 1961. évi rendezési tervének ismertetése. 26-28. o.

\section{Abstract}

The changes in our big cities after the World War II. made radical changes in the spatial structure of the city, the distribution of population, the alter of it's main characteristics. This study shows the most important processes in Debrecen, between 1939 and 1990. The analys is contenrated to the inner-city area, which divided into 42 parts, all of them whith unique specifics.

The population growth, the decreption, the tertiarisation formed characteristic spatial types inside the city. If we can collect and analyse the main phenomenons in the last half century we can understand the most important processes in the past, present and the near future, too. 